\title{
Changes of hospitalization trend in the pediatric cardiology division of a single center by increasing adult with congenital heart disease
}

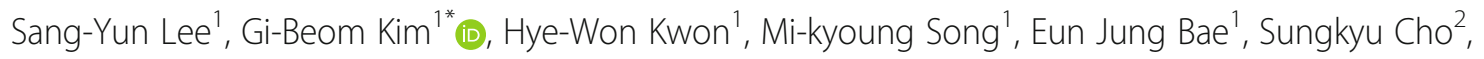
Jae Gun Kwak2, Hong-Gook Lim², Woong-Han Kim² and Jeong-Ryul Lee ${ }^{2}$

\begin{abstract}
Background: As a result of advances in pediatric care and diagnostic testing, there is a growing population of adults with congenital heart disease (ACHD). The purpose of this study was to better define the epidemiology and changes in the trend of hospitalizations for ACHD in Korean society.

Methods: We reviewed outpatient and inpatient data from 2005 to 2017 to identify patient $\geq 18$ years of age admitted for acute care with a congenital heart disease (CHD) diagnosis in the pediatric cardiology division. We tried to analyze changes of hospitalization trend for ACHD.

Results: The ratio of outpatients with ACHD increased 286.5\%, from 11.1\% (1748/15,682) in 2005 to 31.8\% (7795/24, 532 ) in 2017. The number of ACHD hospitalizations increased 360.7\%, from 8.9\% (37/414) in 2005 to 32.1\% (226/ 705) in 2017. The average patient age increased from 24.3 years in 2005 to 27.4 in 2017. The main diagnosis for admission of ACHD is heart failure, arrhythmia and Fontan-related complications. The annual ICU admission percentage was around 5\% and mean length of intensive care unit (ICU) stay was $8.4 \pm 14.6$ days. Mean personal hospital charges by admission of ACHD increased to around two times from 2005 to 2017. (from $\$ 2578.1$ to \$3697.0). Total annual hospital charges by ACHD markedly increased ten times (from $\$ 95,389.7$ to $\$ 831,834.2$ ).

Conclusions: The number of hospital cares for ACHD dramatically increased more than five times from 2005 to 2017. We need preparations for efficient healthcare for adults with CHD such as a multi-dimensional approach, effective communication, and professional training.
\end{abstract}

Keywords: Adult with congenital heart disease

\footnotetext{
* Correspondence: ped9526@snu.ac.kr

'Department of Pediatrics, Seoul National University Children's Hospital,

Seoul National University College of Medicine, 101, Daehak-ro, Jongno-gu,

Seoul 03080, Republic of Korea

Full list of author information is available at the end of the article
}

(c) The Author(s). 2020 Open Access This article is licensed under a Creative Commons Attribution 4.0 International License, which permits use, sharing, adaptation, distribution and reproduction in any medium or format, as long as you give appropriate credit to the original author(s) and the source, provide a link to the Creative Commons licence, and indicate if changes were made. The images or other third party material in this article are included in the article's Creative Commons licence, unless indicated otherwise in a credit line to the material. If material is not included in the article's Creative Commons licence and your intended use is not permitted by statutory regulation or exceeds the permitted use, you will need to obtain permission directly from the copyright holder. To view a copy of this licence, visit http://creativecommons.org/licenses/by/4.0/ The Creative Commons Public Domain Dedication waiver (http://creativecommons.org/publicdomain/zero/1.0/) applies to the data made available in this article, unless otherwise stated in a credit line to the data. 


\section{Background}

Congenital heart disease (CHD) is the most common congenital lesion, and the overall prevalence is known to be 0.8 $\sim 0.9 \%$ [1]. According to a report by the Korea Heart Foundation, around 5000 patients undergo treatment for CHD annually in South Korea, and their mortality is around $2 \%$ (http://www.heart.or.kr). The incidence of adults living with CHD has been increasing every year due to remarkable advances in surgically or percutaneously interventional techniques and devices and knowledge of critical care for patients with CHD [2]. The majority of these adult patients cannot be considered to be completely cured, as most lesions have a chronic course, even after repair. Also, patients who have undergone cardiac surgery are more likely to have vulnerable heart and systemic conditions [3, 4].

In Kim's report [5], he expected that there will be about 70,000 patients in South Korea by the year 2020. The increase in adult CHD patients in South Korea is also a global trend in the developed countries, and special programs for them have been reported in many societies [6, 7]. In this study, we intended to investigate epidemiologic changes of patient population in the pediatric cardiology division by analyzing changes of hospitalization trend for adults with CHD in the pediatric cardiology division of a single tertiary center in South Korea.

\section{Methods}

We reviewed the medical records of outpatients and inpatients from 2005 to 2017 in the pediatric cardiology division of Seoul National University Children's Hospital. We identified adult patients ( $\geq 18$ years old) with a CHD. We analyzed change of hospitalization trend for adults with CHD.

Demographic covariates included age, gender, and year of admission. Each diagnosis was categorized as simple, complex, or unclassified based on the 32nd Bethesda Conference report [3]. According to the 32nd Bethesda Conference report, types of adult patients with simple congenital heart diseases were classified as simple lesions and types of adult patients with congenital heart disease moderate or great severity were classified as complex lesions. Diseases not mentioned in the 32nd Bethesda Conference report were classified as unclassified. The diagnosis classification of 32nd Bethesda Conference report is described in the supplement table.

Diagnoses classified as moderately or severely complex in the 32nd Bethesda Conference document are defined as complex in this analysis. Patients with isolated simple defects and coexisting pulmonary hypertension were categorized as complex. We defined comorbidities based on Elixhauser's comprehensive set of comorbidities [8].

Non-CHD diagnoses were defined by the following International Classification of Diseases (ICD)-10 diagnosis codes: cardiomyopathy, electrophysiology diagnoses, ischemic stroke or transient ischemic attack, soft tissue infection, and pregnancy. Procedures were defined by the following ICD-10 procedure codes: percutaneous patent ductus arteriosus (PDA) or atrial septal defect/ patent foramen ovale (ASD/PFO) closure, implantable cardioverterdefibrillator insertion or revision, pacemaker insertion or revision, and percutaneous coronary intervention.

Primary outcomes of interest were the annual number of visiting the outpatient clinic and admission with all CHD diagnoses, as well as annual admissions for subgroups of the overall population such as simple and complex CHD diagnoses. Secondary outcomes of interest were the frequency of specific diagnoses, procedures associated with hospitalizations for ACHD, hospitalization duration, and hospital charges.

This study used clinical data retrieved from the Seoul National University Hospital Patients Research Environment (SUPREME) system. This study was approved by the institutional review board of Seoul National University Hospital (Approved date: Dec 14, 2018 / IRB number: 1811-059-983) and patient's consent was waived for retrospective study nature.

\section{Results}

We analyzed the annual number of outpatient clinic visits in the pediatric cardiology division of our hospital, and the ratio of adult patients increased from 11.1 to $31.8 \%$ from 2005 to 2017 (Fig. 1). During this period, children patients increased $20.1 \%$ (from 13,934 to 16,737 a year) and adult patients increased 445.9\% (from 1748 to 7795 a year) in the outpatient clinic. In analyzing the annual admission number, the ratio increased from 8.9 to $32.1 \%$ from 2005 to 2017 (Fig. 1b). During this period, the number of children patients admitted increased $27.1 \%$ (from 377 to 479 a year) and adult patients increased $610.8 \%$ (from 37 to 226 a year).

The mean age of adult patients at admission increased from 24.3 to 27.4 years (Fig. 2). The absolute number of adult patients with CHD in the outpatient clinic and admissions increased around 6.1 times from 2005 to 2017.

The annual number of admissions for patients with complex CHD diagnoses is presented in Fig. 3. The ratio of patients with complex CHD did not change from 2005 to 2017 and it was from 70 to $80 \%$. About $10 \%$ of patients each year were in the non-CHD group, most of whom had cardiomyopathy and coronary complication by Kawasaki disease. Functional single ventricle was the most common single complex diagnosis in all years and tetralogy of Fallot (TOF) was second (Fig. 4). Patients with complex CHD were younger on average than those with simple defects $(26.4 \pm 6.9$ years vs. $31.0 \pm 11.6$ years, $p<0.000)$ and did not show a difference in sex ratio. Trends in specific selected diagnoses and procedures for ACHD admissions are presented in Table 1. Among them, arrhythmia and heart failure were common and 


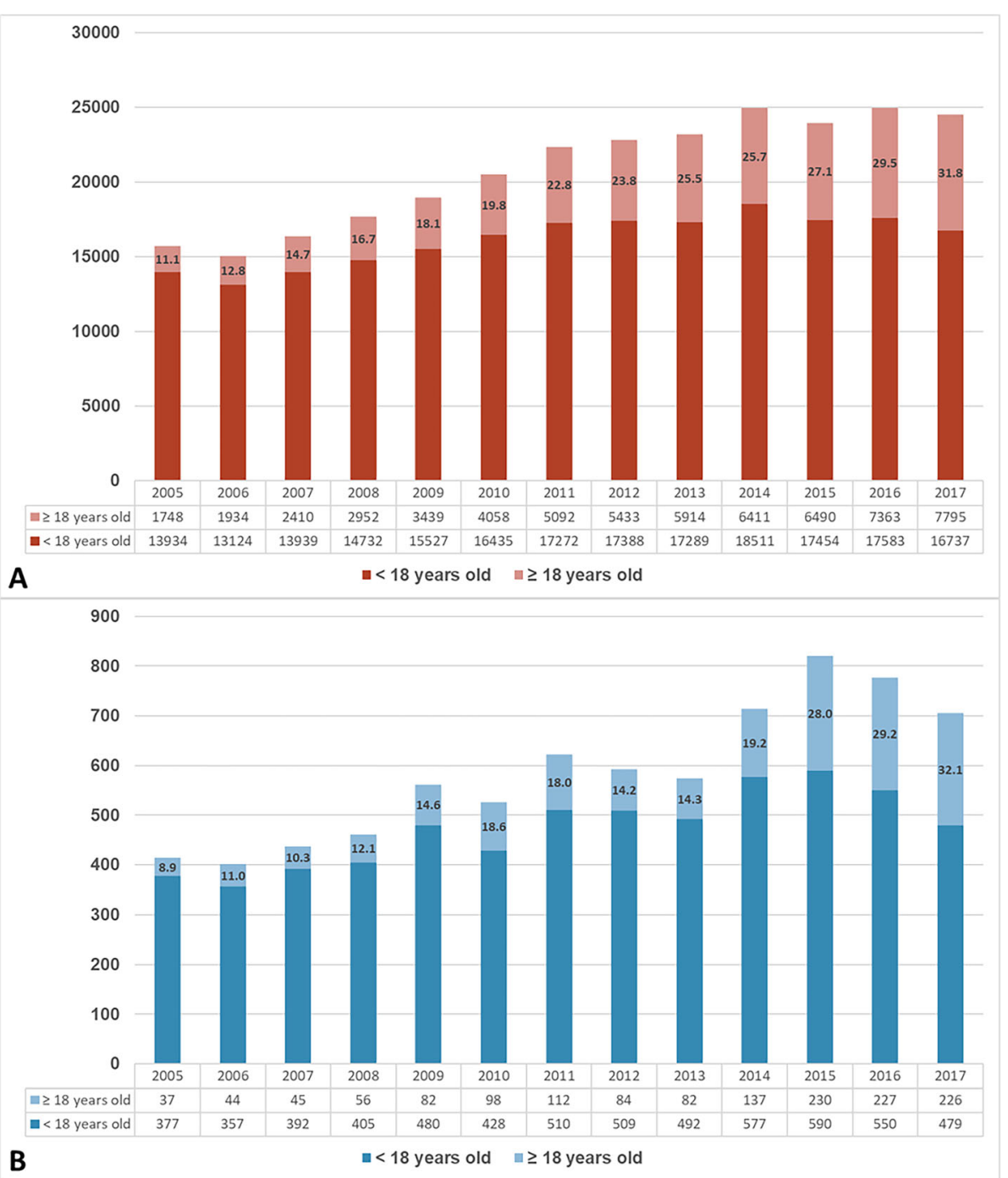

Fig. 1 a Annual number of out-patient clinic and (b) annual number of admission patients in the pediatric cardiology division. The ratio of outpatients with ACHD increased $286.5 \%$, from $11.1 \%(1748 / 15,682)$ in 2005 to $31.8 \%(7795 / 24,532)$ in 2017 . The number of ACHD hospitalizations increased $360.7 \%$, from $8.9 \%$ (37/414) in 2005 to $32.1 \%$ (226/705) in 2017

infection-related complications were the most common diagnosis in the unclassified group according to comorbidities based on Elixhauser's comprehensive set of comorbidities [8]. The mean hospital duration was $8.4 \pm 17.0$ days, and there was no significant difference from 2005 to 2017. (Table 1). The annual ICU admission percentage was around 5\% and mean length of intensive care unit (ICU) stay was $8.4 \pm 14.6$ days. The absolute number of patients who underwent ICU care and duration of ICU stay increased significantly from 2005 to 2017 in recent years (Table 1). Mean personal hospital charges by admission of ACHD increased to around 1.4 times from 2005 to 2017. (from $\$ 2578.1$ to \$3697.0). Total annual hospital charges by ACHD markedly increased 8.7 times (from $\$ 95,389.7$ to $\$ 831,834.2$ ) (Table 1 and Fig. 5).

\section{Discussion}

The Korean Heart Foundation reported that operations for CHD have been performed since 1959 in South Korea, open heart surgery have been popular after the 1980s (http://www.heart.or.kr). About 4000 patients in a year underwent open heart surgery or percutaneous interventions for CHD after the 1980s, and their mortality is currently around $2 \%$. For this reason, the mean age of adults with CHD is younger than other countries, especially the United States $[9,10]$. Additionally, because our subject is only the admission of patients in the pediatric cardiology division, our patients' mean age is younger than in the data of other countries. A unique point in our data is that the number of patients with simple defects is too low. This might be because our subject is 

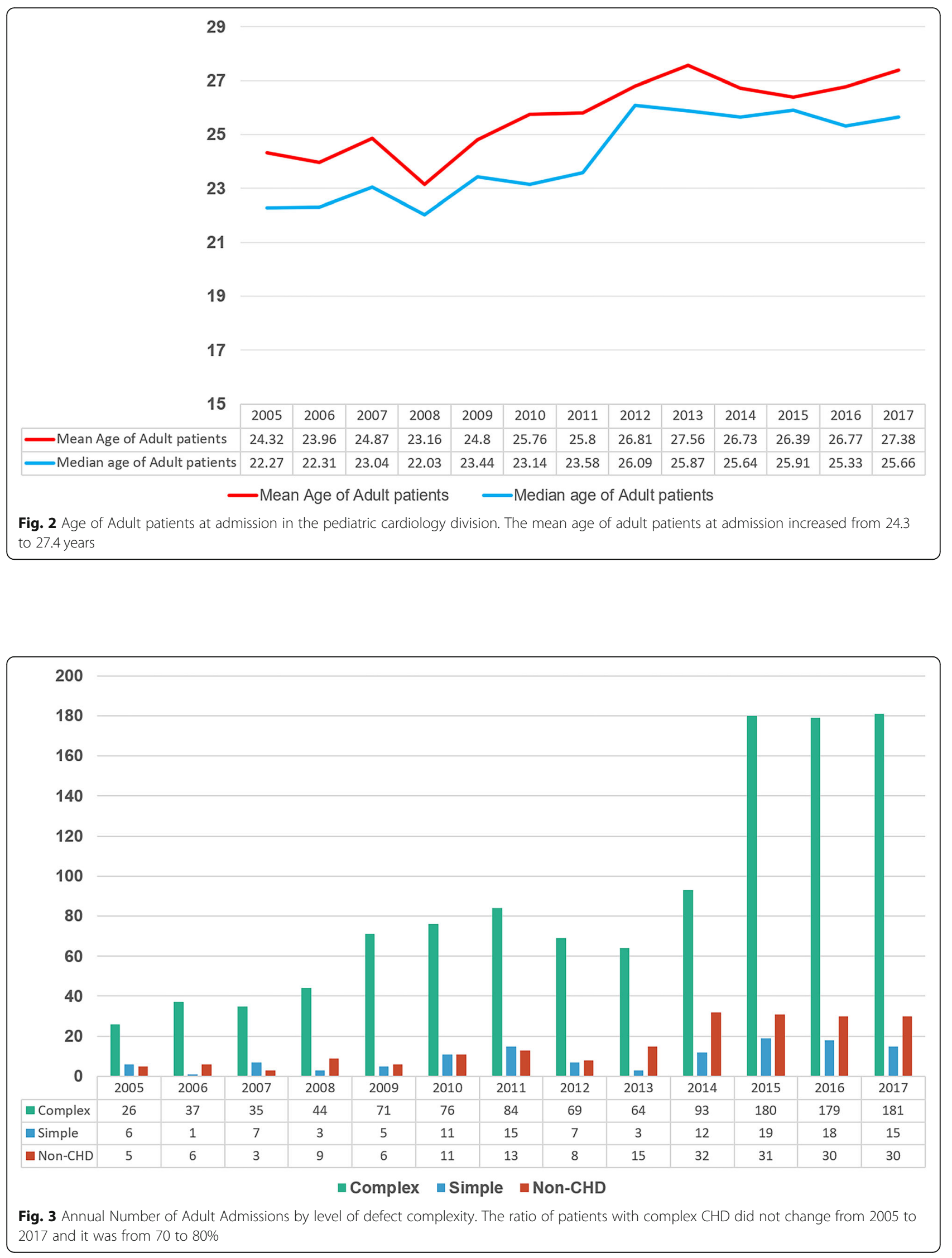


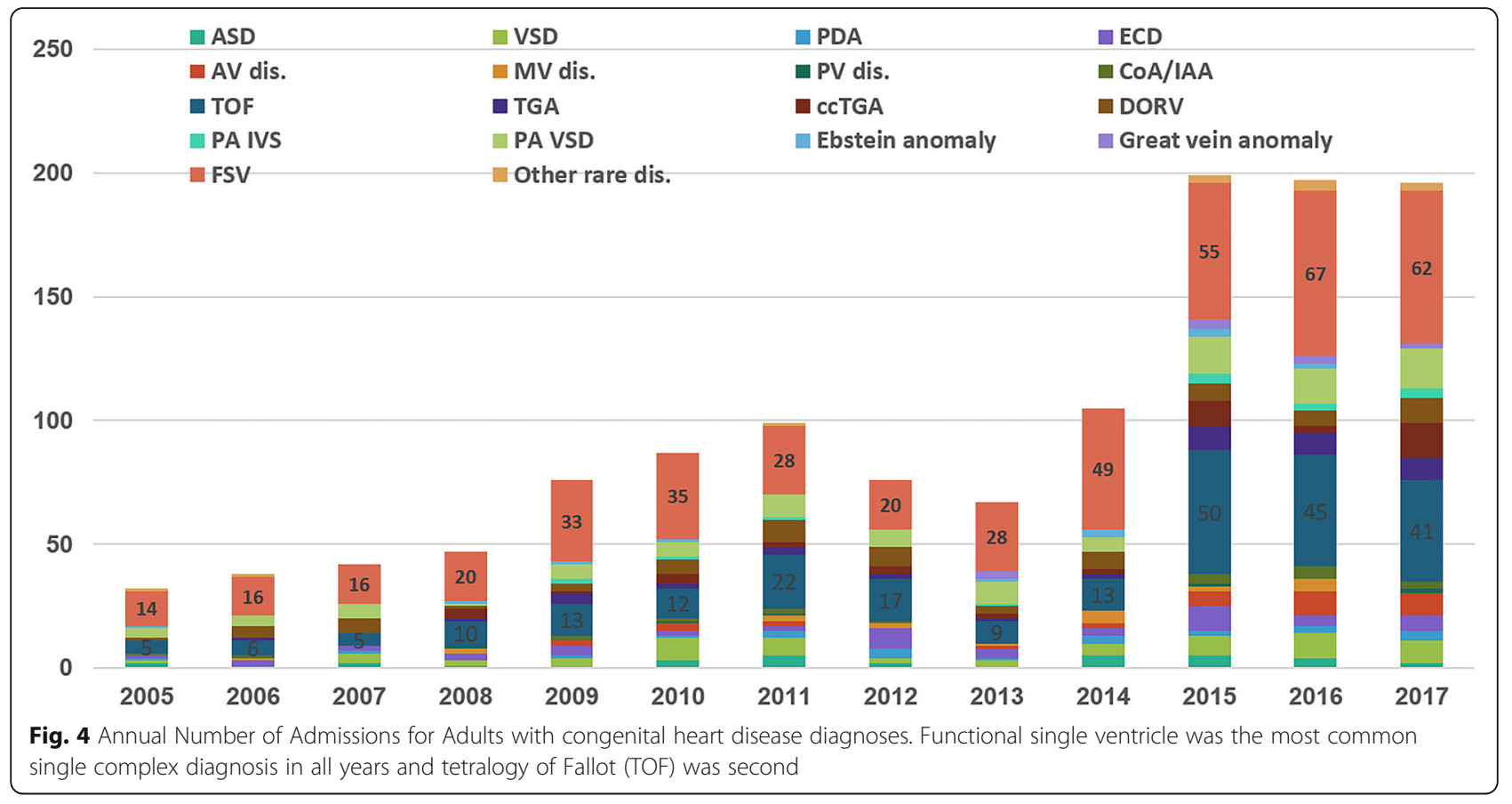

Table 1 Specific Diagnoses and Procedures Associated with Hospitalizations for ACHD Table 3 Frequency of Specific Diagnoses and Procedures Associated with Hospitalizations for ACHD. ( 1200 Korean dollar converted to \$1 US dollar)

\begin{tabular}{|c|c|c|c|c|c|c|c|c|c|c|c|c|c|}
\hline Year & 2005 & 2006 & 2007 & 2008 & 2009 & 2010 & 2011 & 2012 & 2013 & 2014 & 2015 & 2016 & 2017 \\
\hline \multicolumn{14}{|l|}{ Diagnoses } \\
\hline Arrhythmia & 11 & 8 & 14 & 15 & 14 & 20 & 23 & 23 & 25 & 20 & 38 & 40 & 34 \\
\hline Heart failure & 10 & 16 & 9 & 16 & 33 & 40 & 36 & 27 & 15 & 33 & 80 & 74 & 72 \\
\hline Pulmonary HTN & 1 & 4 & 6 & 3 & 7 & 5 & 14 & 5 & 2 & 5 & 6 & 7 & 3 \\
\hline Endocarditis & 0 & 1 & 1 & 1 & 0 & 0 & 1 & 0 & 0 & 3 & 3 & 4 & 3 \\
\hline CAD & 0 & 0 & 0 & 0 & 2 & 3 & 1 & 0 & 1 & 3 & 3 & 5 & 9 \\
\hline \multicolumn{14}{|l|}{ Procedures } \\
\hline Intervention & 4 & 3 & 2 & 1 & 5 & 7 & 5 & 6 & 3 & 12 & 17 & 15 & 12 \\
\hline $\begin{array}{l}\text { Device } \\
\text { (pacemaker/ICD) }\end{array}$ & 2 & 0 & 2 & 0 & 0 & 1 & 3 & 0 & 1 & 1 & 2 & 3 & 4 \\
\hline Unclassified & 4 & 6 & 8 & 11 & 15 & 11 & 16 & 15 & 20 & 28 & 50 & 49 & 59 \\
\hline Non-CHD & 5 & 6 & 3 & 9 & 6 & 11 & 13 & 8 & 15 & 32 & 31 & 30 & 30 \\
\hline Total & 37 & 44 & 45 & 56 & 82 & 98 & 112 & 84 & 82 & 137 & 230 & 227 & 226 \\
\hline $\begin{array}{l}\text { Hospital duration } \\
\text { (days) }\end{array}$ & 7.0 & 10.9 & 8.3 & 8.5 & 8.7 & 8.6 & 10.8 & 7.4 & 8.3 & 8.9 & 8.4 & 9.1 & 6.4 \\
\hline $\begin{array}{l}\text { ICU duration } \\
\text { (days) }\end{array}$ & 2.3 & 2.0 & 3.0 & 2.0 & 2.8 & 4.7 & 4.2 & 3.0 & 8.3 & 13.5 & 11.3 & 13.5 & 8.6 \\
\hline $\begin{array}{l}\text { ICU admission } \\
\text { number }\end{array}$ & $\begin{array}{l}3 / 37 \\
(8.1 \%)\end{array}$ & $\begin{array}{l}4 / 44 \\
(9.1 \%)\end{array}$ & $\begin{array}{l}1 / 45 \\
(2.2 \%)\end{array}$ & $\begin{array}{l}2 / 56 \\
(3.6 \%)\end{array}$ & $\begin{array}{l}4 / 82 \\
(4.9 \%)\end{array}$ & $\begin{array}{l}7 / 98 \\
(7.1 \%)\end{array}$ & $\begin{array}{l}5 / 112 \\
(4.5 \%)\end{array}$ & $\begin{array}{l}2 / 84 \\
(2.4 \%)\end{array}$ & $\begin{array}{l}6 / 82 \\
(7.3 \%)\end{array}$ & $\begin{array}{l}8 / 137 \\
(5.8 \%)\end{array}$ & $\begin{array}{l}16 / 230 \\
(7.0 \%)\end{array}$ & $\begin{array}{l}11 / 227 \\
(4.8 \%)\end{array}$ & $\begin{array}{l}8 / 226 \\
(3.5 \%)\end{array}$ \\
\hline $\begin{array}{l}\text { Mean Hospital } \\
\text { Charges } \\
\text { per patient (US\$) }\end{array}$ & $\$ 2578.1$ & $\$ 2633.0$ & $\$ 2733.4$ & $\$ 2403.8$ & $\$ 2340.8$ & $\$ 2815.5$ & $\$ 3833.7$ & $\$ 3071.4$ & $\$ 4805.9$ & $\$ 5505.5$ & $\$ 4216.1$ & $\$ 5289.7$ & $\$ 3697.0$ \\
\hline $\begin{array}{l}\text { Total Hospital } \\
\text { Charges } \\
\text { per year (US\$) }\end{array}$ & $\begin{array}{l}\$ 95 \\
389.7\end{array}$ & $\begin{array}{l}\$ 115 \\
854.1\end{array}$ & $\begin{array}{l}\$ 123 \\
004.5\end{array}$ & $\begin{array}{l}\$ 134 \\
615.2\end{array}$ & $\begin{array}{l}\$ 191 \\
945.6\end{array}$ & $\begin{array}{l}\$ 275 \\
918.0\end{array}$ & $\begin{array}{l}\$ 429 \\
376.9\end{array}$ & $\begin{array}{l}\$ 257 \\
995.9\end{array}$ & $\begin{array}{l}\$ 394 \\
083.4\end{array}$ & $\begin{array}{l}\$ 754 \\
252.4\end{array}$ & $\begin{array}{l}\$ 969, \\
692.2\end{array}$ & $\begin{array}{l}\$ 1200 \\
767.8\end{array}$ & $\begin{array}{l}\$ 831 \\
834.2\end{array}$ \\
\hline
\end{tabular}




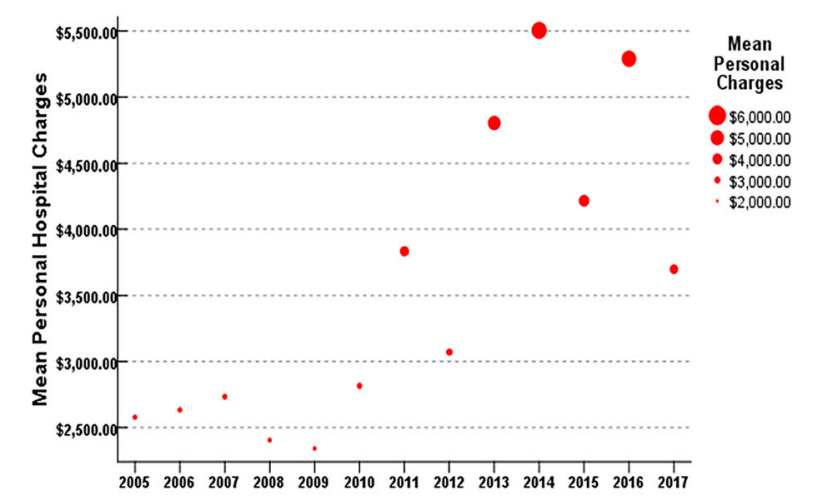

A

Fig. 5 a Mean personal hospital charges and (b) Total annual hospital charges for admission of adults with congenital heart disease (US dollars). Mean personal hospital charges by admission of ACHD increased to around two times from 2005 to 2017. (from \$2578.1 to \$3697.0). Total annual hospital charges by ACHD markedly increased ten times (from $\$ 95,389.7$ to $\$ 831,834.2$ ) only admitted patients in the pediatric cardiology division and our subject age is younger. In other reports, adults with CHD who have simple lesions might have complications at an older age than those with complex lesions [9].

Like research in other countries, our results showed increasing adults with $\mathrm{CHD}$, and their number will be about 70,000 in South Korea by the year 2020 according to Kim's report [5]. In a previous investigation [9] it was reported that this trend derived from improvements in care, increasingly sensitive diagnostic tools, and increasing awareness of the potential relationships between common diseases and CHD. In our country, surgical mortality for CHD was relatively pretty low nowadays and the quality of imaging techniques is relatively so high [11].

The growing population of adults with $\mathrm{CHD}$ requires efficient healthcare organizations. We need a multidimensional approach to defining the role of different healthcare professionals, improvement of communication channels, and certification or training programs for healthcare professionals including physicians, surgeons, and nurses $[2,12]$. A follow-up program or guidelines for specific CHDs might be useful and help physicians with the long-term management of patients and early detection of various complications [2]. In our results, adults with $\mathrm{CHD}$ requiring ICU care and ICU stays have been increased with the increasing total adults with CHD. When adult patients with CHD undergo ICU care, knowledge of CHD might be critical, and the need for pediatric cardiologic intensivists is increasing. Because pediatric cardiologic intensivists usually have experience in post-operative periods, heart failure, mechanical cardiac support, and post-heart transplantation management, they can decide the optimal timing for mechanical cardiac support and heart transplantation [12].
In our results, the main causes of admission for adults with CHD were arrhythmia, heart failure, and single ventricle-related complications. This might be because our hospital is the oldest tertiary institution in South Korea with many patients who had complex CHDs and the ratio of complex CHDs is high. (Fig. 3 and Table 1).

As our results show, total hospital charges for adults with CHD are snowballing. As mentioned before, efficient healthcare for adults with CHD needs a multi-dimensional approach, effective communication, and professional training. With these efforts, healthcare charges for adults with CHD can be saved against a social background where life expectancy is increasing significantly in South Korea.

The principal limitation of this study is that we only analyzed admission cases in the pediatric cardiologic division. Therefore, adults with CHD from other departments with conditions such as metabolic syndrome and pregnancy were not included, although these conditions were not uncommon $[13,14]$. The other limitation is that this result could not reflect true epidemiologic changes of South Korea, because our center is tertiary referral national center and many patients were referred far from our hospital. However, our data is useful for understanding changes in pediatric cardiology trends in one tertiary referral center. Additionally, our data has accuracy and completeness compared to other reports because we used diagnostic codes and reviewed medical records directly, in contrast with other reports that only used diagnostic codes $[9,15,16]$. Although our study was conducted retrospectively, it was difficult to conduct it prospectively on the subject of the study.

\section{Conclusion}

Our study shows an increase in the number and rate of hospital admissions for adults with $\mathrm{CHD}$, and their mean 
age has been increased every year. Main problems of adults with CHD were heart failure, arrhythmia and single ventricle-related complications. Because our subjects are relatively younger than in other countries, these trends will be strongly progressive. We need preparations for efficient healthcare for adults with CHD such as a multi-dimensional approach, effective communication, and professional training.

\section{Supplementary information}

Supplementary information accompanies this paper at https://doi.org/10. 1186/s12872-020-01511-3.

Additional file 1: Supplement table. Each diagnosis of adult patients with congenital heart disease was categorized as simple, complex, or unclassified based on the 32nd Bethesda Conference report [3].

\section{Abbreviations}

ACHD: Adults with congenital heart disease; ASD/PFO: Atrial septal defect/ patent foramen ovale; CHD: Congenital heart disease; ICD: International classification of diseases; ICU: Intensive care unit; PDA: Patent ductus arteriosus; TOF: Tetralogy of Fallot

\section{Acknowledgements}

Not applicable.

\section{Authors' contributions}

SYL and GBK contributed to the design of the study. EJB, SC, JGK, HGL, WHK, and JRL dealt with patients' follow up and contributed to the analysis, while HWK, MKS contributed to the interpretation of data. SYL and GBK drafted the manuscript. All the authors critically revised the manuscript and gave final approval, and agree to be accountable for all aspects of the work, ensuring both its integrity and accuracy. All authors read and approved the final manuscript.

\section{Funding}

This study was not supported by any fund.

\section{Availability of data and materials}

The datasets used and/or analyzed during the current study will be available from the corresponding author on reasonable request.

\section{Ethics approval and consent to participate}

This study was approved by the institutional review board of Seoul National University Hospital (Approved date: Dec 14, 2018 / IRB number: 1811-059983) and patient's consent was waived for retrospective study nature.

\section{Consent for publication}

Not applicable.

\section{Competing interests}

The authors declare that they have no competing interests.

\section{Author details}

${ }^{1}$ Department of Pediatrics, Seoul National University Children's Hospital, Seoul National University College of Medicine, 101, Daehak-ro, Jongno-gu, Seoul 03080, Republic of Korea. ${ }^{2}$ Department of Thoracic and Cardiovascular Surgery, Seoul National University Children's Hospital, Seoul National

University College of Medicine, Seoul, Korea.

Received: 1 February 2020 Accepted: 10 May 2020

Published online: 15 May 2020

\section{References}

1. van der Linde $D$, Konings EE, Slager MA, Witsenburg M, Helbing WA Takkenberg JJ, Roos-Hesselink JW. Birth prevalence of congenital heart disease worldwide: a systematic review and meta-analysis. J Am Coll Cardiol. 2011;58(21):2241-7.
2. Niwa K. Adults with congenital heart disease transition. Curr Opin Pediatr. 2015;27(5):576-80.

3. Warnes CA, Liberthson R, Danielson GK, Dore A, Harris L, Hoffman Jl, Somerville J, Williams RG, Webb GD. Task force 1: the changing profile of congenital heart disease in adult life. J Am Coll Cardiol. 2001;37(5):1170-5.

4. Tobler D, Schwerzmann M, Bouchardy J, Engel R, Stambach D, Attenhofer Jost C, Wustmann K, Schwitz F, Rutz T, Gabriel H, et al. Swiss adult congenital HEart disease registry (SACHER) - rationale, design and first results. Swiss Med Wkly. 2017;147:w14519.

5. Kim GB. Psychosocial adjustment and quality of life of adolescents and adults with congenital heart disease. Korean J Pediatr. 2014;57(6):257-63.

6. Warnes CA, Williams RG, Bashore TM, Child JS, Connolly HM, Dearani JA, del Nido P, Fasules JW, Graham TP Jr, Hijazi ZM, et al. ACC/AHA 2008 guidelines for the Management of Adults with congenital heart disease: a report of the American College of Cardiology/American Heart Association task force on practice guidelines (writing committee to develop guidelines on the management of adults with congenital heart disease). Circulation. 2008; 118(23):e714-833.

7. Baumgartner H, Bonhoeffer P, De Groot NM, de Haan F, Deanfield JE, Galie N, Gatzoulis MA, Gohlke-Baerwolf C, Kaemmerer H, Kilner P, et al. ESC guidelines for the management of grown-up congenital heart disease (new version 2010). Eur Heart J. 2010;31(23):2915-57.

8. Elixhauser A, Steiner C, Harris DR, Coffey RM. Comorbidity measures for use with administrative data. Med Care. 1998;36(1):8-27.

9. Opotowsky AR, Siddiqi OK, Webb GD. Trends in hospitalizations for adults with congenital heart disease in the U.S. J Am Coll Cardiol. 2009;54(5):460-7.

10. Agarwal S, Sud K, Menon V. Nationwide Hospitalization Trends in Adult Congenital Heart Disease Across 2003-2012. J Am Heart Assoc. 2016;5(1).

11. Jang SY, Seo SR, Moon JR, Cho EJ, Kim E, Chang SA, Song J, Huh J, Kang IS, Kim DK, et al. Prevalence and mortality of congenital heart disease in Korean adults. Medicine (Baltimore). 2018;97(27):e11348.

12. Willems R, de Hosson M, De Backer J, Annemans L. Opinions of general and adult congenital heart disease cardiologists on care for adults with congenital heart disease in Belgium: a qualitative study. Cardiol Young. 2019:1-7.

13. Niwa K. Metabolic syndrome in adult congenital heart disease. Korean Circ J. 2019;49(8):691-708.

14. Niwa K. Adult congenital heart disease with pregnancy. Korean Circ J. 2018; 48(4):251-76.

15. Billett J, Majeed A, Gatzoulis M, Cowie M. Trends in hospital admissions, inhospital case fatality and population mortality from congenital heart disease in England, 1994 to 2004. Heart. 2008;94(3):342-8.

16. Wu MH, Lu CW, Chen HC, Kao FY, Huang SK. Adult Congenital Heart Disease in a Nationwide Population 2000-2014: Epidemiological trends, arrhythmia, and standardized mortality ratio. J Am Heart Assoc. 2018:7(4).

\section{Publisher's Note}

Springer Nature remains neutral with regard to jurisdictional claims in published maps and institutional affiliations.

\section{Ready to submit your research? Choose BMC and benefit from:}

- fast, convenient online submission

- thorough peer review by experienced researchers in your field

- rapid publication on acceptance

- support for research data, including large and complex data types

- gold Open Access which fosters wider collaboration and increased citations

- maximum visibility for your research: over $100 \mathrm{M}$ website views per year

At $\mathrm{BMC}$, research is always in progress.

Learn more biomedcentral.com/submission 